\title{
Biotransformation of rare earth oxide nanoparticles eliciting microbiota imbalance
}

Huizhen Zheng ${ }^{1 \dagger}$, Zonglin Gu ${ }^{2 \dagger}$, Yanxia Pan ${ }^{1}$, Jie Chen ${ }^{1}$, Qianqian Xie ${ }^{1}$, Shujuan Xu , Meng Gao ${ }^{1}$, Xiaoming Cai ${ }^{3}$, Shengtang Liu', Weili Wang ${ }^{1}$, Wei Li ${ }^{1}, X_{i}$ Liu $^{1}$, Zaixing Yang ${ }^{1 *}$, Ruhong Zhou ${ }^{1,4}$ and Ruibin $\mathrm{Li}^{1 *}$ (D)

\begin{abstract}
Background: Disruption of microbiota balance may result in severe diseases in animals and phytotoxicity in plants. While substantial concerns have been raised on engineered nanomaterial (ENM) induced hazard effects (e.g., lung inflammation), exploration of the impacts of ENMs on microbiota balance holds great implications.

Results: This study found that rare earth oxide nanoparticles (REOs) among 19 ENMs showed severe toxicity in Gram-negative $\left(\mathrm{G}^{-}\right)$bacteria, but negligible effects in Gram-positive $\left(\mathrm{G}^{+}\right)$bacteria. This distinct cytotoxicity was disclosed to associate with the different molecular initiating events of REOs in $\mathrm{G}^{-}$and $\mathrm{G}^{+}$strains. $\mathrm{La}_{2} \mathrm{O}_{3}$ as a representative REOs was demonstrated to transform into $\mathrm{LaPO}_{4}$ on $\mathrm{G}^{-}$cell membranes and induce $8.3 \%$ dephosphorylation of phospholipids. Molecular dynamics simulations revealed the dephosphorylation induced more than 2-fold increments of phospholipid diffusion constant and an unordered configuration in membranes, eliciting the increments of membrane fluidity and permeability. Notably, the ratios of $\mathrm{G}^{-} / \mathrm{G}^{+}$reduced from 1.56 to 1.10 in bronchoalveolar lavage fluid from the mice with $\mathrm{La}_{2} \mathrm{O}_{3}$ exposure. Finally, we demonstrated that both IL-6 and neutrophil cells showed strong correlations with $\mathrm{G}^{-} / \mathrm{G}^{+}$ratios, evidenced by their correlation coefficients with 0.83 and 0.92 , respectively.

Conclusions: This study deciphered the distinct toxic mechanisms of $\mathrm{La}_{2} \mathrm{O}_{3}$ as a representative REO in $\mathrm{G}^{-}$and $\mathrm{G}^{+}$ bacteria and disclosed that $\mathrm{La}_{2} \mathrm{O}_{3}$-induced membrane damages of $\mathrm{G}^{-}$cells cumulated into pulmonary microbiota imbalance exhibiting synergistic pulmonary toxicity. Overall, these findings offered new insights to understand the hazard effects induced by REOs.
\end{abstract}

Keywords: Rare earth oxide, Nanotoxicity, Biotransformation, Microbiota imbalance, Pulmonary inflammation

\footnotetext{
* Correspondence: zxyang@suda.edu.cn; liruibin@suda.edu.cn

${ }^{\dagger}$ Huizhen Zheng and Zonglin Gu contributed equally to this work.

'State Key Laboratory of Radiation Medicine and Protection, School for Radiological and Interdisciplinary Sciences (RAD-X), Collaborative Innovation Center of Radiological Medicine of Jiangsu Higher Education Institutions, Soochow University, Suzhou 215123, Jiangsu, China

Full list of author information is available at the end of the article
}

(c) The Author(s). 2021 Open Access This article is licensed under a Creative Commons Attribution 4.0 International License, which permits use, sharing, adaptation, distribution and reproduction in any medium or format, as long as you give appropriate credit to the original author(s) and the source, provide a link to the Creative Commons licence, and indicate if changes were made. The images or other third party material in this article are included in the article's Creative Commons licence, unless indicated otherwise in a credit line to the material. If material is not included in the article's Creative Commons licence and your intended use is not permitted by statutory regulation or exceeds the permitted use, you will need to obtain permission directly from the copyright holder. To view a copy of this licence, visit http://creativecommons.org/licenses/by/4.0/ The Creative Commons Public Domain Dedication waiver (http://creativecommons.org/publicdomain/zero/1.0/) applies to the data made available in this article, unless otherwise stated in a credit line to the data. 


\section{Background}

Microorganisms play critical roles in animal metabolism and Earth's biogeochemical cycles as they are responsible for litter decomposition (e.g., Bacillus subtilis and Enterobacter), nitrogen fixation (like Rhizobium), oxygen production (e.g., Synechococcus and Cyanobacteria), as well as nutrition (e.g., Lactobacillus and Bifidobacterium) and energy (e.g., Shewanella) supplies [1,2]. After several billion years of evolution, versatile microbes have evolved diverse local communities [3], a.k.a. microbiota, to maintain mutualistic relationships with humans, animals and plants. Any disruption of microbial community may elicit severe diseases in living systems or spell disasters for local ecosystems [4]. Remarkably, certain pollutants generated from industrial developments have been demonstrated to significantly affect microbial communities, resulting in severe environmental and health issues. For instance, the exposure of environmental persistent organic pollutants (POPs), e.g., 2,3,7,8-tetrachlorodibenzofuran, with $24 \mu \mathrm{g} / \mathrm{kg}$ in the diet for 5 days may altered the gut microbiota by shifting the ratio of Firmicutes to Bacteroidetes, which was associated with the alteration of bile acid metabolism [5]. Moreover, imbalance of microbial community in lung may have an important role in progression of pulmonary disorders, such as chronic obstructive pulmonary disease, asthma, cystic fibrosis and lung cancer [6]. Since inhalable pollutants are the causes of lung diseases, a focus shift towards the study of their toxicological effects on microbial community has come into questions.

During the past decade, a number of nanoparticles have potential environmental exposure risk during their lifecycles including material synthesis and transportation, nanoproduct fabrication, consumption and recycle [7]. Some engineered nanomaterials (ENMs) have been found to affect the biological function and viability of microorganisms [8]. For instance, GO and $\mathrm{MoS}_{2}$ nanomaterials with mechanical damage and surface oxidative activities were reported to kill bacteria by disrupting cellular membranes $[9,10]$. Vanadium pentoxide nanoparticles and Pt hollow nanomaterials with peroxidase-like activities were demonstrated to impair the activities of both Gram-negative $\left(\mathrm{G}^{-}\right)$and Gram-positive $\left(\mathrm{G}^{+}\right)$bacteria $[11,12]$. In general, these nanomaterials have been reported to show non-preference for diverse microorganisms, exhibiting indiscriminate toxicities via ROS generation [10], membrane damage [13], DNA duplication inhibition [14], etc. However, it is unclear whether any ENM may affect microbiota balance.

In this study, we investigated the impacts of 19 ENMs on $\mathrm{G}^{-}$and $\mathrm{G}^{+}$bacteria and specifically focused on the distinct toxicity effects of rare earth oxide (REO) nanoparticles in $\mathrm{G}^{+}$and $\mathrm{G}^{-}$bacteria. To decipher the molecular initiating events (MIEs) of the hazard effect, we visualized the biotransformation of $\mathrm{La}_{2} \mathrm{O}_{3}$ at nano-bio interfaces and revealed the dynamical interaction process by molecular dynamics (MD) simulations. Based on the MD simulation predictions, we then performed fluorescence polarization and $\beta$-galactosidase release assays to validate the impacts of $\mathrm{La}_{2} \mathrm{O}_{3}$ on membrane fluidity and permeability, respectively. The effects of $\mathrm{La}_{2} \mathrm{O}_{3}$ were validated in lung and soil microbial communities by Gram staining and 16S rRNA-based sequencing approaches. We examined the impacts of microflora imbalance on lung tissues and made a hypothesis that the biotransformation of $\mathrm{La}_{2} \mathrm{O}_{3}$ in lung may elicit the microbiota imbalance and pulmonary toxicity.

\section{Methods \\ Materials}

Bacterial culture medium including Luria-Bertani (LB) broth and Tryptic Soy Broth (TSB) were purchased from Sangon Biotech (Shanghai, China). The sources of ENMs, including REOs and other nanoparticles were displayed in Table S1. 1,2-distearoyl-sn-glycero-3-phosphocholine (PC, 18:0/18:0, Mw: 790, No. 850365) was purchased from Avanti (USA). Beta-Glo Assay System (E4720) used for membrane permeability test was purchased from Promega (USA). 4'-(trimethylammonio) diphenylhexatriene (AM9625) was obtained from AAT Bioquest Inc. (USA) to determine the membrane fluidity. Bacterial counting colorimetric assay kit (K511) used to quantify the viability of bacteria was purchased from Biovision Inc. (USA). Live/Dead BacLight bacterial viability kit (L7007) from Thermo Fisher (USA) was used to examine the viability of bacterial populations by a fluorescence microscope. Alexa Fluor 594 conjugate of wheat germ agglutinin (WGA, W11262) and 4',6-Diamidino-2-Phenylindole (DAPI, D3571) purchased from Thermo Fisher (USA) were used to examined $\mathrm{G}^{+}$and $\mathrm{G}^{-}$ bacteria. Colistin (C4461) was purchased from SigmaAldrich (St. Louis, Mo, USA). ELISA kits for detection of IL-1 $\beta$ and IL- 6 were purchased from BD biosciences (San Jose, CA, USA); MCP-1 ELISA kit was purchased from R\&D (Minneapolis, MN, USA). Quick-Diff staining kit was purchased from Yeasen Biotechnology (Shanghai, China).

\section{Transmission electron microscope (TEM) and X-ray diffraction (XRD) characterizations}

$\mathrm{La}_{2} \mathrm{O}_{3}$ or $\mathrm{LaPO}_{4}(5 \mathrm{mg} / \mathrm{mL})$ was diluted into alcohol at $50 \mu \mathrm{g} / \mathrm{mL}$ and dispersed by a probe sonicator (ScientzIID, Scientz, China) at $32 \mathrm{~W}$ for $30 \mathrm{~s}$ (10 s on, $2 \mathrm{~s}$ off). Drops of alcohol suspensions were placed on copper grids for air drying at room temperature. Then they were observed by TEM at $120 \mathrm{kV}$ (Tecnai G20, FEI, USA). After the nanoparticles drying at vacuum desiccation for overnight, their crystal structures were detected 
by XRD (D8 Advance, Bruker, Germany) with $\mathrm{Cu} \mathrm{K} \alpha$ radiation.

E. coli cells $\left(\sim 10^{8}\right.$ CFUs $)$ at exponential phase were exposed to $1 \mathrm{~mL}$ saline solution containing $250 \mu \mathrm{g} / \mathrm{mL}$ $\mathrm{La}_{2} \mathrm{O}_{3}$ in a $1.5 \mathrm{~mL}$ Eppendorf tube. After $2 \mathrm{~h}$ incubation in a shaker $\left(200 \mathrm{rpm}, 37^{\circ} \mathrm{C}\right)$, the treated cells were collected by $6000 \mathrm{~g}$ centrifugation for $5 \mathrm{~min}$ and fixed in $2.5 \%$ glutaraldehyde for $30 \mathrm{~min}$ at room temperature. Followed by overnight incubation, osmium tetroxide (1\% $\mathrm{w} / \mathrm{v}$ ) was used to stain the fixed cells for $1 \mathrm{~h}$. Then we dehydrated the samples in a graded series of ethanol (30, 50, 70, 90, 100\%). The samples were finally embedded in Epon, followed by propylene oxide treatment. Cell sections were cut by an ultramicrotome (EM UC7, Leica, Wetzlar, Germany), picked up on Formvar-coated copper grids for further staining by uranyl acetate and Reynolds lead citrate. The grids were observed by TEM (Tecnai G2 spirit BioTwin, FEI, USA) coupled with energy-dispersive X-ray (EDX).

\section{Bacterial activity assessment}

E. coli cells were cultured at LB broth, and B. subtilis cells were cultured in medium containing $5.0 \mathrm{~g}$ peptone, $3.0 \mathrm{~g}$ beef extract and $5.0 \mathrm{~g} \mathrm{NaCl}$ per liter. When they were grown to exponential phase $\left(\mathrm{OD}_{600}\right.$ at 0.6 to 0.8$)$, the cells were collected by centrifugation of $1 \mathrm{~mL}$ suspensions at $6000 \mathrm{~g}$ for $5 \mathrm{~min}$ and dispersed in $5 \mathrm{~mL}$ saline. ENM suspensions were prepared by dilution of 5 $\mathrm{mg} / \mathrm{mL}$ ENM stock solutions into saline solutions. After dispersion by a probe sonicator (Scientz-IID, Scientz, China) at $32 \mathrm{~W}$ for $15 \mathrm{~s}$, gradient concentrations $(0,62.5$, 125,250 and $500 \mu \mathrm{g} / \mathrm{mL}$ ) of ENM suspension were acquired and added into 96 -well plates $(100 \mu \mathrm{L} /$ well $)$. Aliquots of $100 \mu \mathrm{L}$ bacterial suspension were exposed to $100 \mu \mathrm{L}$ ENMs in 96-well plates. The final concentrations of ENMs were 0, 31.75, 62.5, 125 and $250 \mu \mathrm{g} / \mathrm{mL}$. After $2 \mathrm{~h}$ incubation at $37^{\circ} \mathrm{C}$ in a shaker $(200 \mathrm{rpm})$ away from light, the bacterial activities were determined by a bacterial counting colorimetric assay kit according to the manufacture's protocol. In detail, aliquots of $20 \mu \mathrm{L}$ colorimetric assay solutions were added into each well for additional 30-60 min incubation. Three replicates were performed at each dosage. We collected the supernatants by centrifugation at $1000 \mathrm{~g}$ for $5 \mathrm{~min}$ (Sorvall ST16R, Thermo, USA) and transferred them into a new 96-well plate for OD detection at $460 \mathrm{~nm}$ by a microplate reader (Synergy NEO HTS, Biotek, USA). Cell viabilities were calculated by formula 1 :

$$
\text { Cell viability }(\%)=\frac{\mathrm{OD}_{\mathrm{x}}-\mathrm{OD}_{\mathrm{b}}}{\mathrm{OD}_{0}-\mathrm{OD}_{\mathrm{b}}} \times 100 \%
$$

where $\mathrm{OD}_{\mathrm{x}}, \mathrm{OD}_{0}$ and $\mathrm{OD}_{\mathrm{b}}$ are the absorbance of ENM- treated bacteria, untreated bacteria and medium blanks, respectively.

\section{Confocal microscopy imaging of bacterial cells}

E.coli and B. subtilis cells $\left(\sim 10^{8} \mathrm{CFUs}\right)$ cultured at exponential phase were collected and washed twice by saline solution. Then the bacterial cells were centrifuged at $6000 \mathrm{~g}$ for $5 \mathrm{~min}$ (Allegra 64R, Beckman, USA) and dispersed in $0.5 \mathrm{~mL}$ saline containing $250 \mu \mathrm{g} / \mathrm{mL} \mathrm{La}_{2} \mathrm{O}_{3}$ nanoparticles. After $2 \mathrm{~h}$ incubation, aliquots of $0.5 \mathrm{~mL}$ bacterial suspension were stained for $15-20 \mathrm{~min}$ at room temperature by mixing $1.5 \mu \mathrm{L}$ Live/Dead bacterial viability kit. Aliquots of $5 \mu \mathrm{L}$ stained cells were subsequently dropped on a microslide and visualized by a confocal microscope (UltraView VoX, PerkinElmer, USA) with a 100X oil immersion objective at $488 / 500 \mathrm{~nm}$ for SYTO 9 and $488 / 635 \mathrm{~nm}$ for prodium iodide (PI). WGA conjugated with Alexa Fluor 594 was used to differentiate $\mathrm{G}^{+}$ strains. The microbial communities collected from soil or animal lungs were suspended in $1 \mathrm{~mL}$ saline solutions containing $1 \mu \mathrm{g} / \mathrm{mL}$ WGA and $10 \mu \mathrm{g} / \mathrm{mL}$ DAPI. After 15 min incubation at room temperature, cells were collected by centrifugation at $6000 \mathrm{~g}$ for $5 \mathrm{~min}$ and sufficiently washed by saline for three times. Then the bacterial cells were dispersed in $100 \mu \mathrm{L}$ saline and visualized by a confocal microscope (FV1200, Olympus, Japan) with a $60 \mathrm{X}$ oil immersion objective at excitation/emission wavelengths of $405 / 450 \mathrm{~nm}$ for blue fluorescence and $488 / 635 \mathrm{~nm}$ for red fluorescence. Six images were obtained for each sample.

\section{Colony forming unit (CFU) counting}

CFU assay was employed to determine the toxicity of $\mathrm{La}_{2} \mathrm{O}_{3}, \mathrm{TiO}_{2}$ and $\mathrm{Ag}$ nanoparticles in E.coli, P. aeruginosa, S. aureus and B. subtilis. In detail, E.coli and P. aeruginosa were cultured in LB broth. S. aureus was cultured in TSB broth, and B. subtilis was cultured in its medium containing $5.0 \mathrm{~g}$ peptone, $3.0 \mathrm{~g}$ beef extract and $5.0 \mathrm{~g} \mathrm{NaCl}$ per liter. Cell suspensions $(1 \mathrm{~mL})$ at exponential phase were centrifuged at $6000 \mathrm{~g}$ for $5 \mathrm{~min}$ (Allegra $64 \mathrm{R}$, Beckman, USA). After washing twice by saline, the cell pellets were dispersed in $1 \mathrm{~mL}$ saline solutions containing $250 \mu \mathrm{g} / \mathrm{mL}$ nanoparticles. After $2 \mathrm{~h}$ incubation, seven serial dilutions were performed by adding $1 \mathrm{~mL}$ of bacterial suspension into $9 \mathrm{~mL}$ saline. Aliquots of $100 \mu \mathrm{L}$ diluted bacterial suspension were added to agar plates with $10 \mathrm{~cm}$ diameter. After $24 \mathrm{~h}$ incubation at $37^{\circ} \mathrm{C}$, appropriate colonies $(20 \sim 100)$ on agar plates were selected to count colony numbers. Three replicates were performed at each dilution. CFU and survival rates were calculated by formula 2 and 3 :

$$
\mathrm{CFU}\left(\mathrm{mL}^{-1}\right)=\mathrm{C}_{\mathrm{n}} / 0.1 \times 10^{\mathrm{n}}
$$




$$
\text { Survival rate }(\%)=\left(\mathrm{CFU}_{\mathrm{ENM}} / \mathrm{CFU}\right) \times 100 \%
$$

Where $C_{n}$ is the colony number on agar plates at $n^{\text {th }}$ dilution; $\mathrm{CFU}_{\mathrm{ENM}}$ and $\mathrm{CFU}$ represent the colony numbers of ENM-treated and untreated bacteria, respectively.

\section{$\mathrm{La}_{2} \mathrm{O}_{3}$-lipid interaction measurement}

In order to investigate the detailed interaction between nanoparticle and cell membrane, phosphatidylcholine (PC) liposomes were prepared to mimic the cell membrane by a film dispersion method. In detail, we dissolved $2 \mathrm{mg}$ PC in $2 \mathrm{~mL}$ of chloroform and transferred them into a $10 \mathrm{~mL}$ round-bottom flask. A lipid film was prepared by removing chloroform with a rotary evaporator at $160 \mathrm{mbar}, 150 \mathrm{rpm}$ for $30 \mathrm{~min}$. After that, ultrasonic dispersion was performed in $2 \mathrm{~mL} \mathrm{DI} \mathrm{H}_{2} \mathrm{O}$ for 30 min. PC liposomes were collected by centrifugation at $30000 \mathrm{~g}$ for $5 \mathrm{~min}$ and re-suspended in $2 \mathrm{~mL}$ saline. $\mathrm{La}_{2} \mathrm{O}_{3}(250 \mu \mathrm{g} / \mathrm{mL})$ was exposed to $1 \mathrm{~mL}$ liposome solutions in a $2 \mathrm{~mL}$ Eppendorf tube. After $4 \mathrm{~h}$ incubation in a shaker, the pellets were obtained by centrifugation at $30000 \mathrm{~g}$ for $5 \mathrm{~min}$ and fully suspended in $1 \mathrm{~mL}$ chloroform by $5 \mathrm{~min}$ vortex for extraction of PC molecules. The suspensions were centrifuged at $15000 \mathrm{~g}$ for $5 \mathrm{~min}$ to collect the supernatants, which were subjected to liquid chromatography coupled to mass spectrometry (LC-MS) analysis according to a reported protocol [15]. In detail, it was conducted on an Agilent 1100 Series LC system (Agilent Technologies, Santa Clara, CA, USA) with a reversed phase HPLC column $(2.1 \mathrm{~mm} \times 150 \mathrm{~mm}$, $100 \AA, 5 \mu \mathrm{m}$ ) coupled to a mass spectrometer (Thermo Fisher Scientific, Waltham, MA, USA). Samples were separated with an isocratic gradient of isopropanol and acetonitrile $(45: 55, \mathrm{v} / \mathrm{v})$ containing $10 \mathrm{mM}$ ammounium formate at $200 \mu \mathrm{L} / \mathrm{min}$ flow rate. Full scan MS detection was conducted in positive ionization mode to collect 100 to $1000 \mathrm{~m} / \mathrm{z}$ data, which was analyzed by Xcalibur software.

\section{Molecular dynamics simulation}

Coarse-grained model [16] was employed to simulate the bacterial membrane by using CHARMM-GUI Martini Bilayer Maker $[17,18]$ with the outer membrane modeled by pure POPE and the inner membrane by a mixture of POPE and POPG (3,1 ratio), similar to our previous protocol [13]. The initial membrane had a lateral dimension of $20 \times 20 \mathrm{~nm}$. Two simulation systems were constructed, with one for the control system (i.e. the normal bacterial membrane) and the other for the dephosphorylated system. In the dephosphorylated system, some POPE lipids (proportion of $\sim 9.0 \%$ based on LC-MS quantification) located on the outer leaflet were "mutated" to dephosphorylated POPE (de-POPE) by deleting $\mathrm{NH} 3$ and PO4 beads to mimic our experimental settings. The MD simulations were performed using GROMACS software package (version 5.0.2) [19] and the Martini force field (version 2.2) [20]. The temperature and pressure were controlled by velocityrescaling thermostat (at $303 \mathrm{~K}$ ) [21] and the ParrinelloRahman barostat (1 bar semi-isotropic pressure coupling) [22], respectively. The periodic boundary conditions $(\mathrm{PBC})$ were implemented in all directions $(\mathrm{X}, \mathrm{Y}$ and Z). We performed all simulations with an integration time step of $20 \mathrm{fs}$. Electrostatic interactions were modulated with the reaction field method using dielectric constants of 15 and infinity for charge screening in the short-range and long-range regimes, following the recommended simulation settings for coarse-grained Martini (version 2). The short-range cutoff distance for the electrostatic interactions was set to $1.2 \mathrm{~nm}$. The potential shift Verlet scheme was used to cut off the Lennard-Jones potential at long ranges. All simulations followed the basic protocol obtained from CHARMMGUI. Each system ran for $1 \mu \mathrm{s}(1000 \mathrm{~ns})$. The order parameter $\left(-S_{\mathrm{CD}}\right)$ of coarse-grained lipids could be calculated based on the equation following previous studies [23], which reflected the quantification of the relative order of the hydrocarbon tails.

$$
S_{\mathrm{CD}}=\frac{1}{2}\left(3 \cos ^{2} \theta_{i}-1\right)
$$

$\theta_{i}$ is the angle between the bilayer normal and the local orientation of neighboring hydrocarbon beads of the lipids.

\section{Membrane fluidity and permeability assays}

E. coli and B. subtilis cells at exponential phase were collected by centrifugation at $6000 \mathrm{~g}$ for $5 \mathrm{~min}$ and suspended in $1 \mathrm{~mL}$ saline solutions, respectively. $\mathrm{La}_{2} \mathrm{O}_{3}$ or $\mathrm{LaPO}_{4}$ nanoparticles at $250 \mu \mathrm{g} / \mathrm{mL}$ were exposed to $500 \mu \mathrm{L}$ bacterial suspensions in $1.5 \mathrm{~mL}$ Eppendorf tubes. After $2 \mathrm{~h}$ incubation at $37^{\circ} \mathrm{C}$ in a shaker, the suspensions were mixed with $5 \mu \mathrm{L}$ TMA-DPH stock solutions (2 $\mathrm{mM}$ ) and incubated for $30 \mathrm{~min}$ at $37^{\circ} \mathrm{C}$. The incubated cells were collected by centrifugation at $6000 \mathrm{~g}$ for $5 \mathrm{~min}$ and dispersed in $500 \mu \mathrm{L}$ saline solution after washing three times. Aliquots of $100 \mu \mathrm{L}$ bacterial suspensions were transferred into a 96-well plate and examined at ex/em $360 / 460 \mathrm{~nm}$ by a microplate reader (Synergy NEO HTS, Biotek, USA) with a 66 FP module. Three replicates were performed for each sample. The obtained fluorescence polarization (FP) value of TMA-DPH is a reliable index for membrane fluidity evaluation [24].

A $\beta$-Glo assay reagent (Promega) was used to detect $\beta$ galactosidase release from damaged cells for membrane permeability evaluation. In detail, E. coli and B. subtilis cells $\left(\sim 10^{8}\right.$ CFUs) were incubated with $500 \mu \mathrm{L}$ saline 
solutions containing $250 \mu \mathrm{g} / \mathrm{mL}$ nanoparticles $\left(\mathrm{La}_{2} \mathrm{O}_{3}\right.$ or $\mathrm{LaPO}_{4}$ ) or $500 \mu \mathrm{L}$ cell lysis buffer (positive control). The untreated cells were used as negative control. After $2 \mathrm{~h}$ incubation at $37^{\circ} \mathrm{C}$ in a shaker, the cells were centrifuged at $15000 \mathrm{~g}$ for $5 \mathrm{~min}$ to collect supernatants. Aliquots of $50 \mu \mathrm{L}$ supernatants were transferred into 96well plates to react with $50 \mu \mathrm{L} \beta$-galactosidase substrate for $30 \mathrm{~min}$ at room temperature. The luminescence intensities were determined by a microplate reader (Synergy NEO HTS, Biotek, USA). Three replicates were performed for each sample. The cell membrane permeability was calculated by following formula 5 :

$$
\beta \text {-galactosidase release }(\%)=\frac{I_{\mathrm{a}}}{I_{\text {neg }}+I_{\text {pos }}} \times 100 \%
$$

Where $I_{\mathrm{a}}, I_{\text {neg }}$ and $I_{\text {pos }}$ represent the luminescence intensities of samples, negative and positive controls, respectively.

\section{Animal experiments}

Eight-week-old male C57BL/6 mice from Peng Sheng Biological Technology (Nanjing, Jiangsu, China) were housed in groups of two to four mice per cage under standard laboratory conditions $\left(25^{\circ} \mathrm{C} ; 60 \%\right.$ relative humidity and $12 \mathrm{~h}$ light $/ 12 \mathrm{~h}$ dark cycle) by Soochow University guidelines. Our animal protocols were approved by the Committee of Animal Research and Ethics in Soochow University. Ten mice were anesthetized by intraperitoneal injection of sodium pentobarbital $(200 \mathrm{mg} /$ $\mathrm{Kg}$ ) in a total volume of $80-100 \mu \mathrm{L}$ and randomly divided into two groups. Each group included five mice. One group was exposed to $2 \mathrm{mg} / \mathrm{Kg} \mathrm{La}_{2} \mathrm{O}_{3}$ by oropharyngeal aspiration. In detail, aliquots of $50 \mu \mathrm{L}$ nanoparticle suspensions were instilled at the back of the tongue in anesthetized animals $(n=5)$. Another group subjected to $50 \mu \mathrm{L}$ saline solutions was used as control. After $24 \mathrm{~h}$ exposure, over-anesthetized mice $(400 \mathrm{mg} / \mathrm{Kg})$ were sacrificed to collect BALF by bilateral thoracotomy. Furthermore, to explore the relationships between lung inflammation and the microflora imbalance, mice were firstly exposed to $2 \mathrm{mg} / \mathrm{Kg} \mathrm{La} \mathrm{L}_{3}$ as previous description. At $4 \mathrm{~h}$ post injection, colistin solutions were instilled into mouse lungs $(n=5)$ at different doses $(0,0.6$, $2,4 \mathrm{mg} / \mathrm{Kg}$ ). Mice merely exposed to $4 \mathrm{mg} / \mathrm{Kg}$ colistin were used as a control group. The BALF was obtained by using a $1 \mathrm{~mL}$ syringe with a G22 $\times 1$ "flat needle after $24 \mathrm{~h}$ exposure, which was collected into $2 \mathrm{~mL}$ tubes by thrice syringing $0.8 \mathrm{~mL}$ PBS to wash airways in animal lungs. While the immune cells in BALF were collected by centrifugation at $800 \mathrm{~g}$ for cell counting, the lung microbial communities were obtained by centrifugation at $6000 \mathrm{~g}$ for Gram staining. The supernatants were used for detection of IL-6, IL-1 $\beta$, and MCP-1 by ELISA according to the manufacture instructions. To examine pathology changes, the lung tissues were fixed for $\mathrm{H} \& \mathrm{E}$ staining according to a standard protocol [25].

\section{Statistical analysis}

All experiments were repeated at least thrice with three to six replicates. Data were expressed as mean \pm standard deviation (SD) from at least three replicates. Data analysis was performed by two-tailed Student's t-test. The difference was regarded as statistical significance if $p<0.05$.

\section{Results}

Toxicity assessments of ENMs in $\mathrm{G}^{+}$and $\mathrm{G}^{-}$bacteria

Nineteen ENMs including REOs, metal-based and carbon-based nanoparticles were characterized by zeta potential and hydrodynamic analyzer. As shown in Table S1, all of the ENMs except for graphene oxide (GO) exhibited spherical morphologies with primary sizes at 10 $\sim 100 \mathrm{~nm}$ and significant agglomerations with hydrodynamic sizes at $70 \sim 460 \mathrm{~nm}$. Their zeta potential ranged from -23.7 to $36.4 \mathrm{mV}$. In terms of the tested bacteria strains, they should meet the following criteria: i) reported in pulmonary microflora; ii) commercially available; iii) biosafety level $\leq$ BSL2. As a result, four $\mathrm{G}^{-}$ strains (E. coli, $P$. aeruginosa, $V$. harveyi, S. typhimurium) and two $\mathrm{G}^{+}$strains (S. aureus, B. subtilis) were selected to examine the toxic effects of ENMs (Table S2). To assess the hazard effects of ENMs on $\mathrm{G}^{+}$and $\mathrm{G}^{-}$ bacteria, cell viabilities of E.coli and B. subtilis were examined by colorimetric assay after exposure to ENMs at $0-250 \mu \mathrm{g} / \mathrm{mL}$. The acquired cell viability data were integrated into a heat map to visualize the toxic effects on E.coli and B. subtilis cells, where red, yellow and green colors represented strong, moderate and negligible toxicity effects. As shown in Fig. 1a, the ENMs could be divided into three subgroups (sub-1 to 3) based on their effects on two bacterial strains. While sub-3 group, including $\mathrm{TiO}_{2}, \mathrm{SiO}_{2}, \mathrm{SnO}_{2}, \mathrm{In}_{2} \mathrm{O}_{3}$ and $\mathrm{ZrO}_{2}$ nanoparticles showed green dots with $>82.0 \%$ cell viabilities on both E. coli and B. subtilis, sub-2 group involving $\mathrm{Cr}_{2} \mathrm{O}_{3}$, $\mathrm{Fe}_{2} \mathrm{O}_{3}, \mathrm{MnO}_{2}, \mathrm{NiO}_{2}, \mathrm{Ag}, \mathrm{CuO}$ and $\mathrm{GO}$ showed from green to red with the exposure dosageincrement. By comparison, all seven REOs (sub-1 group) including $\mathrm{CeO}_{2}, \mathrm{Yb}_{2} \mathrm{O}_{3}, \mathrm{Pr}_{6} \mathrm{O}_{11}, \mathrm{Sm}_{2} \mathrm{O}_{3}, \mathrm{La}_{2} \mathrm{O}_{3}, \mathrm{Gd}_{2} \mathrm{O}_{3}$ and $\mathrm{NdO}_{2}$ displayed significant decrement of cell viability in $E$. coli, but limited decline in B. subtilis. Moreover, $\mathrm{La}_{2} \mathrm{O}_{3}, \mathrm{Ag}$ and $\mathrm{TiO}_{2}$ were selected as representative particles of three subgroups of ENMs to detect their effects in E.coli, $P$. aeruginosa, $S$. aureus and $B$. subtilis by $\mathrm{CFU}$ assays (Fig. 1b). As a result, Ag and $\mathrm{TiO}_{2}$ nanoparticles exhibited either strong toxicity (survival rates $<0.01 \%$ ) or negligible bactericidal effects in $\mathrm{G}^{-}$and $\mathrm{G}^{+}$bacteria. In 

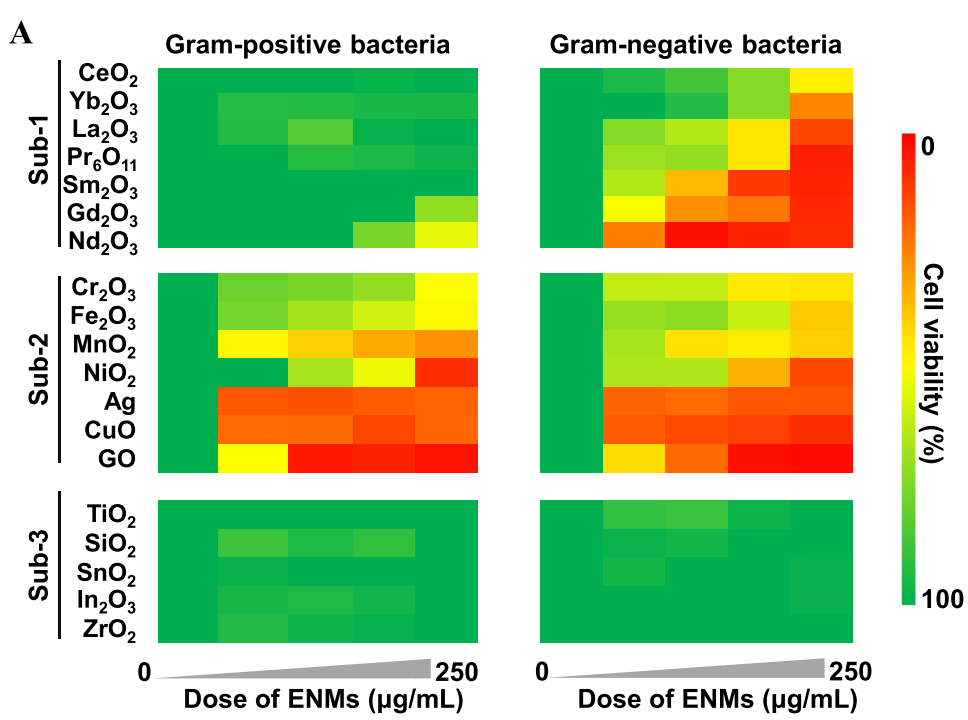

B

C
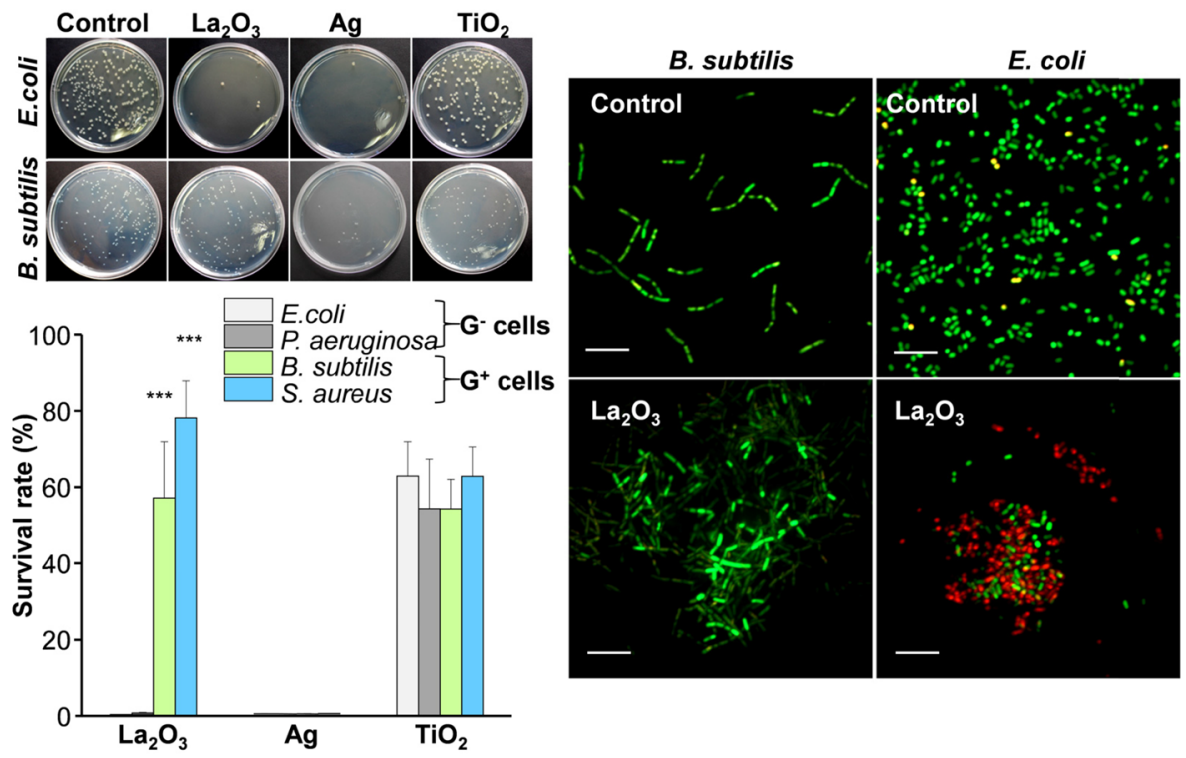

Fig. 1 Comparison of cell viabilities of $\mathrm{G}^{+}$and $\mathrm{G}^{-}$bacteria exposed to ENMs. a Heat maps displaying the toxicity of ENMs in E. coli and B. subtilis cells. E. coli and B. subtilis suspensions were exposed to different nanoparticles for $2 \mathrm{~h}$. Then the cell viabilities were determined by bacteria counting colorimetric assay. Three replicates were conducted for each dosage. b Survival rate examination by CFU assay. The colonies of $E$. coli, $P$. aeruginosa, S. aureus and B. subtilis were counted after exposure to $\mathrm{La}_{2} \mathrm{O}_{3}$ at $250 \mu \mathrm{g} / \mathrm{mL}$. Columns and error bars represent the mean and the standard deviation of three replicates. ${ }^{* *} p<0.001$ compared to $\mathrm{G}^{-}$cells by two-tailed Student's t-test. c Live/Dead staining. E. coli and B. subtilis cells were incubated with $\mathrm{La}_{2} \mathrm{O}_{3}$ and stained by a Live/Dead staining kit for confocal microscopy imaging. Scale bar is $7 \mu \mathrm{m}$

contrast, $\mathrm{La}_{2} \mathrm{O}_{3}$ treatment led to $<0.4 \%$ survival rates in two $\mathrm{G}^{-}$bacterial strains, but limited effects in $\mathrm{G}^{+}$bacteria. Moreover, $\mathrm{La}_{2} \mathrm{O}_{3}$ showed dose-dependent toxicity in other two $\mathrm{G}^{-}$strains, including $V$. harveyi and $S$. typhimurium (Figure S1). To further visualize the impact of $\mathrm{La}_{2} \mathrm{O}_{3}$ in $\mathrm{G}^{-}$and $\mathrm{G}^{+}$bacteria, we conducted a confocal microscope following by the Live/Dead staining. As shown in Fig. 1c, a majority of E. coli cells exposed to $\mathrm{La}_{2} \mathrm{O}_{3}$ allowed PI across membranes to bind with DNA molecules and displayed intense red fluorescence, while most B. subtilis cells emitted green fluorescence by SYTO9.

\section{Biotransformation of $\mathrm{La}_{2} \mathrm{O}_{3}$ at the nano-bio interfaces}

TEM was performed to examine the interaction of $\mathrm{La}_{2} \mathrm{O}_{3}$ and bacterial cells. As shown in Fig. 2a, spherical $\mathrm{La}_{2} \mathrm{O}_{3}$ nanoparticles bound with $E$. coli cells and transformed to needle-like pellets intercalated into cell membranes. These transformed pellets containing abundant phosphorous elements were distinctively different to the 

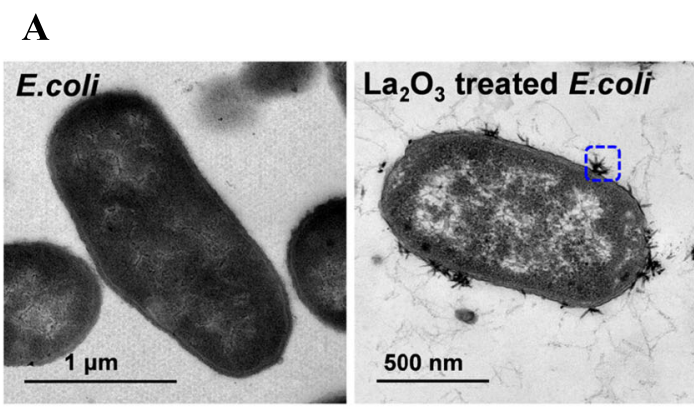

B
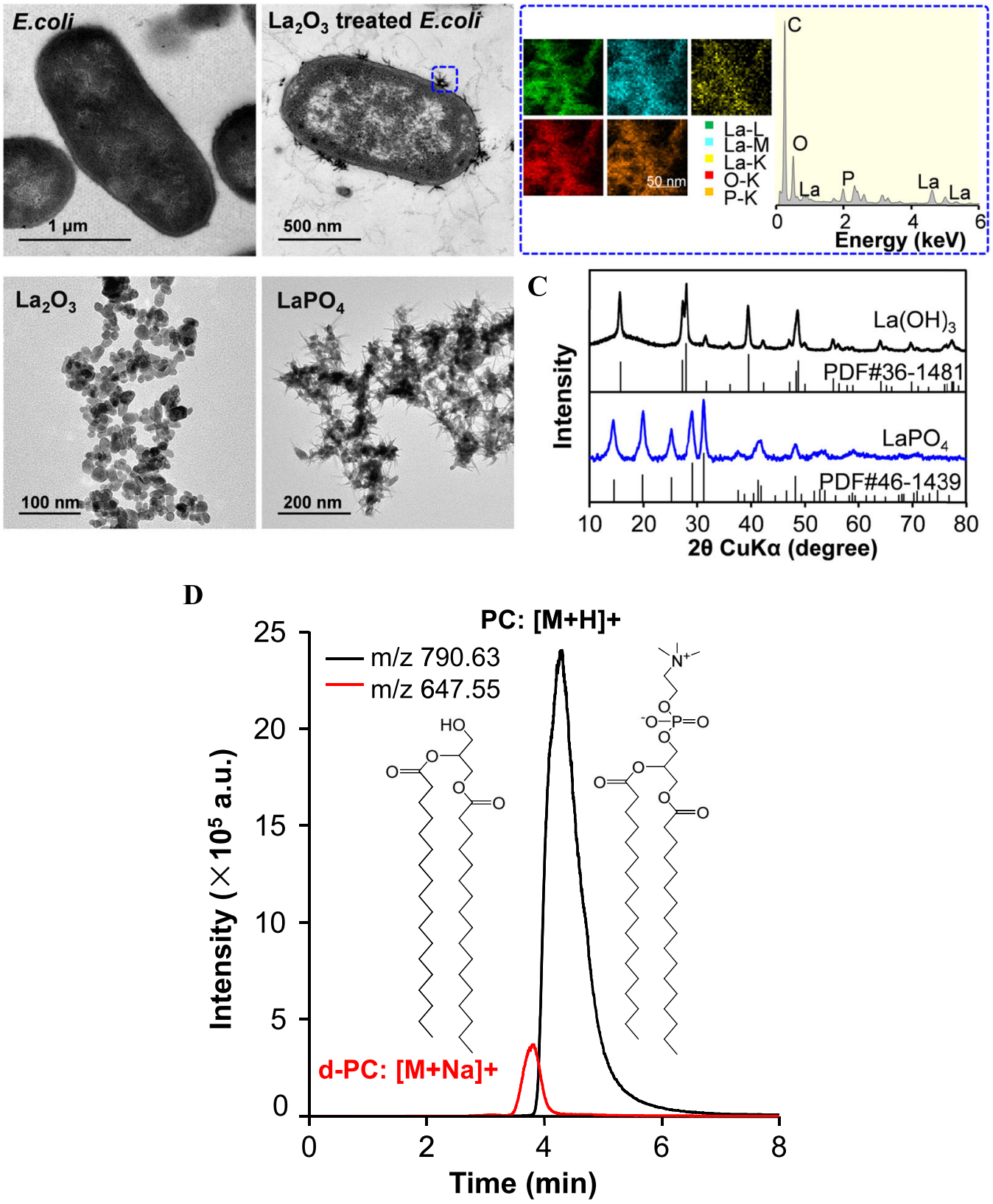

Fig. 2 Assessments of the interaction at $\mathrm{La}_{2} \mathrm{O}_{3}$-membrane interface. a Visualizing $\mathrm{La}_{2} \mathrm{O}_{3}$ in $E$. coli by TEM. E. coli cells were exposed to $\mathrm{La}_{2} \mathrm{O}_{3}$ at $250 \mathrm{\mu g} / \mathrm{mL}$. After fixation in glutaraldehyde, cells were stained and sliced for TEM observation. Pristine $\mathrm{La}_{2} \mathrm{O}_{3}$ and $\mathrm{LaPO}_{4}$ were also examined by TEM. $\mathbf{b}$ EDX spectra and elemental mapping analysis. The chemical composite of pellets transformed at the interfaces of cell membrane were examined. c XRD analysis for the pristine particles and $\mathrm{LaPO}_{4}$. $\mathbf{d} L \mathrm{LC}-\mathrm{MS}$ analysis of PC exposed to $\mathrm{La}_{2} \mathrm{O}_{3}$. After $4 \mathrm{~h}$ incubation with $L \mathrm{~L}_{2} \mathrm{O}_{3}$, $\mathrm{PC}$ was collected and extracted for LC-MS examination

pristine $\mathrm{La}_{2} \mathrm{O}_{3}$ nanoparticles, but similar to hexagonal $\mathrm{LaPO}_{4}$, evidenced by EDX analysis and XRD assessment (Fig. 2b-c). To examine the transformation at the nanobio interfaces, phosphatidylcholine (PC) liposomes were prepared to simulate the phospholipid outer layer of $\mathrm{G}^{-}$ bacteria and subjected to analysis by LC-MS after incubation with $\mathrm{La}_{2} \mathrm{O}_{3}$. As a result, beside of the PC molecular ion peak at $\mathrm{m} / \mathrm{z} 790.63$, a dephosphorylation peak $(\mathrm{m} / \mathrm{z}$ 647.55) was examined, yielding $8.3 \%$ dephosphorylated PC (de-PC) molecules (Fig. 2d). In addition, disaccharide with $\beta-1,4$ glycosidic bonds was used to simulate peptidoglycan of $\mathrm{G}^{+}$bacteria. LC-MS analysis showed 
that $\mathrm{La}_{2} \mathrm{O}_{3}$ had no influence on the chemical structure of disaccharide molecules (Figure S2).

\section{Molecular dynamics simulation of membrane damages} MD simulations were performed to analyze the impact of dephosphorylation on the behaviors of cell membrane at the molecular level. We simulated two systems: one for normal bacterial membrane (served as the control system) and one for dephosphorylated membrane. The normal bacterial membrane consists of an outer leaflet with pure palmitoyloleoylphosphatidylethanolamine
(POPE) and an inner leaflet with mixed POPE/palmitoyloleoylphosphatidylglycerol (POPG) of 3:1 proportion. Meanwhile, the dephosphorylated membrane was prepared via partial dephosphorylation of normal membrane lipids (Figure S3). The processed membrane with a dephosphorylated proportion of $9.0 \%$ (Fig. 3a) was modeled based on the experimental findings as discussed above. After an unbiased simulation for the duration of $1000 \mathrm{~ns}$, the dephosphorylated membrane showed an obviously morphological alteration as compared with the initial setup (Fig. 3a). Specifically, the dephosphorylated
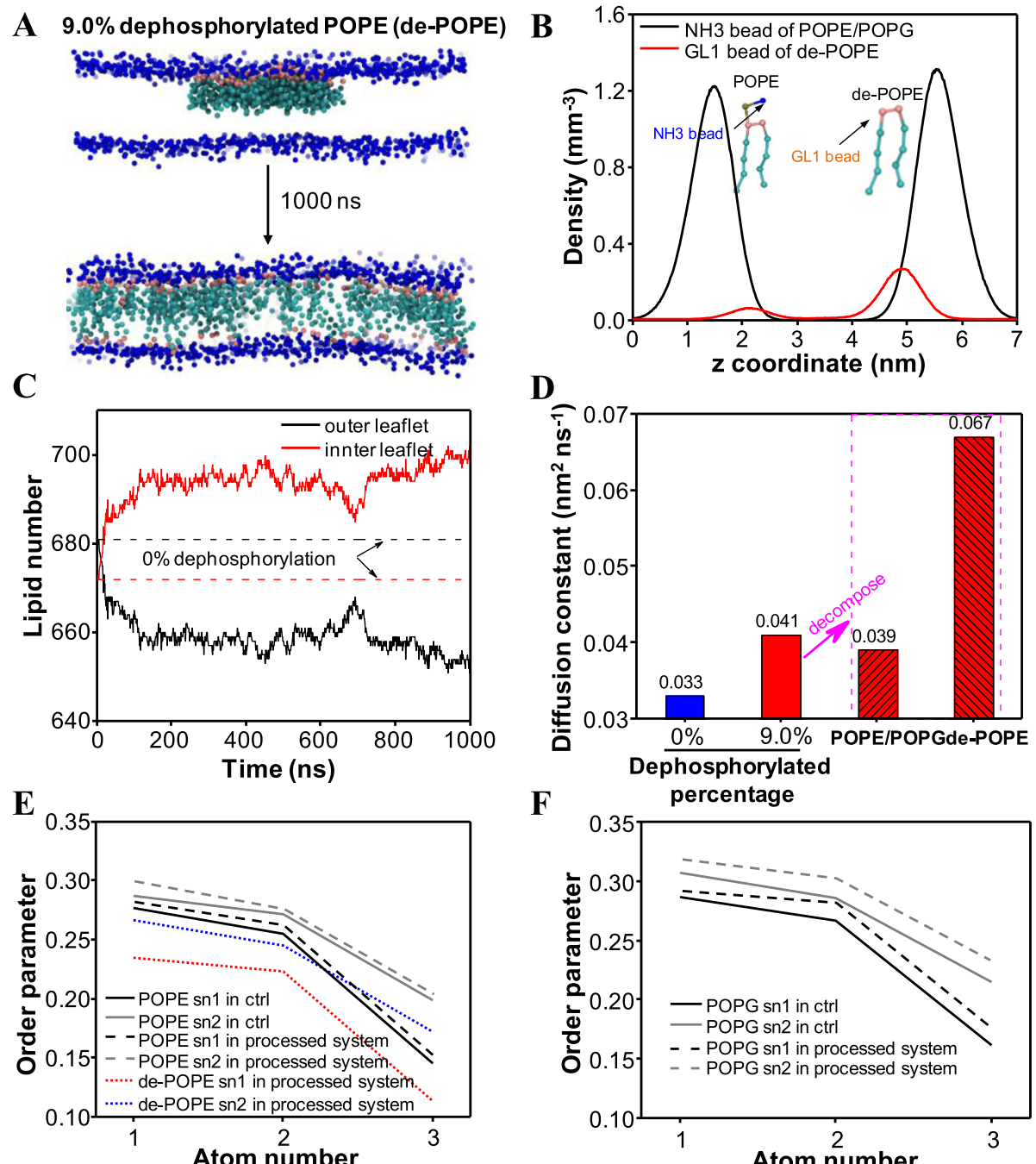

Fig. 3 Molecular dynamics simulation revealing the robust disruption of cell membranes triggered by dephosphorylated lipids. a Structural information of the processed membrane with 9.0\% de-POPE. Blue dots represent heads of normal POPE and POPG while other dots indicate dePOPEs. The upper and lower pictures are the initial and final configurations of membrane for 1000 ns simulation. $\mathbf{b}$ Densities of NH3 beads of POPE/POPG (black) and GL1 beads of de-POPE (red) along $z$ axis. The inserted pictures are the representations of NH3 bead of POPE/POPG and GL1 bead of de-POPE. c Lipid numbers of two membrane leaflets in control and processed systems. The dashed lines indicate the lipid numbers of the normal membrane, whereas the solid lines indicate the lipid numbers of the processed membrane (dephosphorylated membrane). $\mathbf{d}$ Lateral diffusion constants of different lipids. The left two histograms exhibit the lateral diffusion constants of the entire membrane in control (blue) and processed (red) systems. The right two histograms decompose the diffusion constant of the processed membrane into the diffusion constants of normal POPE/POPG and de-POPE. e Order parameters of POPE in control system and POPE/de-POPE in processed system. sn-1 and sn-2 indicate two tails of each lipid. $\mathbf{f}$ Order parameters of POPG in control and processed systems 
POPEs (de-POPEs) dispersed freely inside the twodimensional bilayer. To quantify the distribution of different lipids, we calculated the density distributions of POPE/POPG heads and de-POPE heads along the normal direction after $1000 \mathrm{~ns}$. As shown in Fig. 3b, dePOPEs were detected in either outer leaflet or inner leaflet. Lipid number alterations also demonstrated the same tendencies (Fig. 3c). By contrast, in the normal membrane, the lipid numbers in two leaflets presented two constant values. Subsequently, we computed the membrane fluidity by computing the lateral diffusion constant. As shown in Fig. 3d, the lateral diffusion constant of membrane in the processed system $(9.0 \%$ dephosphorylation) was 0.041 , exhibiting higher than that in the control system. By decomposing the lateral diffusion constant into the lateral diffusion constants of normal lipids and de-POPEs, we found that de-POPEs presented a very large value of lateral diffusion constant, whereas the diffusion constant change of POPE/POPG was much milder. Moreover, the order parameters of all lipids in two systems were assessed (Fig. 3e-f). Notably, the order parameters of two tails (i.e., sn-1 and sn-2) of both POPE and POPG in processed system became larger than that in the control system. In contrast, the order parameters of de-POPE decreased dramatically.

\section{Assessment of membrane disruption}

To verify the effect of $\mathrm{La}_{2} \mathrm{O}_{3}$ on phospholipid lateral and vertical diffusion by $\mathrm{MD}$ simulations, we monitored membrane fluidity and permeability in $\mathrm{G}^{-}$and $\mathrm{G}^{+}$cells by fluorescence polarization and $\beta$-galactosidase release assays, respectively. As shown in Fig. 4a, E. coli cells exposed to $\mathrm{La}_{2} \mathrm{O}_{3}$ showed a fluorescence polarization (FP) value of $533.3 \pm 0.6$, significantly lower $\left(p=2.03 \times 10^{-6}\right)$ than the control cells. Interestingly, E. coli cells exposed to $\mathrm{LaPO}_{4}$ showed $562.0 \pm 2.0 \mathrm{FP}$ value, similar to the control cells. By comparison, in B. subtilis cells, both $\mathrm{La}_{2} \mathrm{O}_{3}$ and $\mathrm{LaPO}_{4}$ treatments exhibited the approximate FP values with the control group. To assess the impacts of $\mathrm{La}_{2} \mathrm{O}_{3}$ on membrane permeability, $\beta$-galactosidase release was detected in $\mathrm{G}^{-}$and $\mathrm{G}^{+}$cells by a luminescent substrate [10]. As shown in Fig. $4 \mathrm{~b}, \mathrm{La}_{2} \mathrm{O}_{3}$ nanoparticles induced $12 \% \beta$-galactosidase release from $E$. coli, significant higher $\left(p=2.61 \times 10^{-7}\right)$ than the control and $\mathrm{LaPO}_{4}$ treated cells, whereas $\mathrm{La}_{2} \mathrm{O}_{3}$ treatment elicited limited $\beta$ galactosidase release in $B$. subtilis cells.

\section{Effects of $\mathrm{La}_{2} \mathrm{O}_{3}$ on microbial communities}

To evaluate the effect of $\mathrm{La}_{2} \mathrm{O}_{3}$ on microbial communities, bacterial gram staining was conducted to examine the ratio of $\mathrm{G}^{-}$and $\mathrm{G}^{+}$strains in lung microbial communities. $\mathrm{G}^{+}$strains in lung samples could be positively stained by Alexa Fluor 594 labeled wheat germ agglutinin (WGA), emitting red fluorescence under confocal microscope. The impacts of $\mathrm{La}_{2} \mathrm{O}_{3}$ on each microbial community were determined by Image $J$ analysis of the portion of $\mathrm{G}^{+}$cells. As shown in Fig. 5a, while a considerable portion $(60.8 \%)$ of $\mathrm{G}^{-}$cells denying the binding to WGA could be visualized in untreated lung microbial communities, $\mathrm{La}_{2} \mathrm{O}_{3}$ treatment showed substantial red fluorescent $\mathrm{G}^{+}$cells and relatively lower abundance of $\mathrm{G}^{-}$cells $(51.3 \%)$, resulting in the decrease of $\mathrm{G}^{-} / \mathrm{G}^{+}$ ratios from 1.56 to 1.10 (Fig. 5b). This microbial community changes were accompanied by significant increments of neutrophil count and cytokines (IL-6, IL-1 $\beta$ and MCP-1) in bronchoalveolar lavage fluid (BALF) (Fig. 5c). To explore the relationships between pulmonary microflora imbalance and inflammation, we deliberately disrupted the microbial communities in mouse lungs by exposure to different concentrations of colistin, which
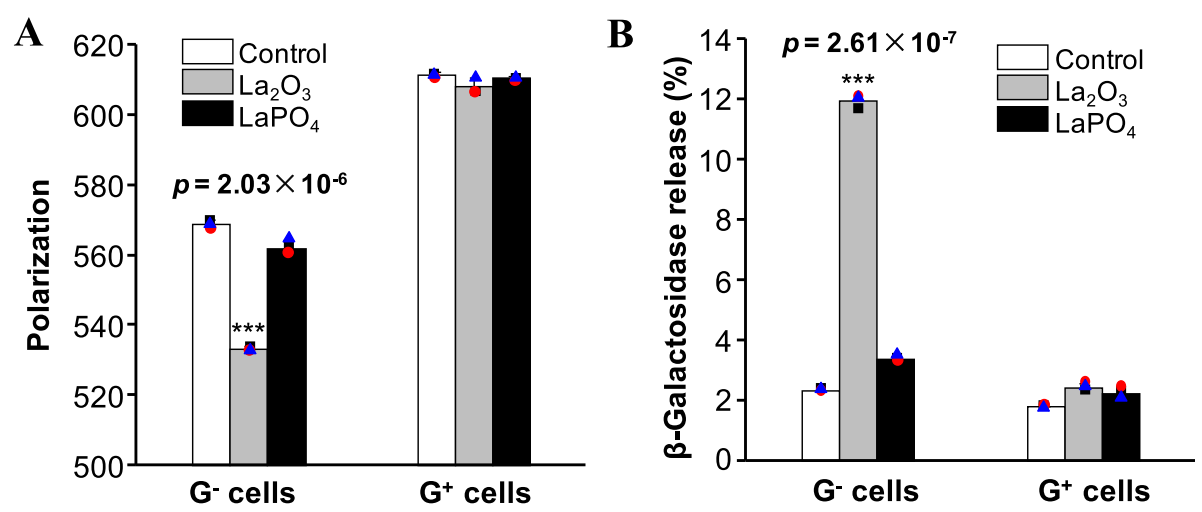

Fig. 4 Validation of $\mathrm{La}_{2} \mathrm{O}_{3}$ induced membrane fluidity and permeability changes. a Detection of the polarization of TMA-DPH intercalating in cell membranes. E. coli and B. subtilis cells were incubated with $250 \mu \mathrm{g} / \mathrm{mL} \mathrm{La} \mathrm{O}_{3}$ or $\mathrm{LaPO}_{4}$ for $2 \mathrm{~h}$. TMA-DPH probe $(5 \mu \mathrm{L}, 2 \mathrm{mM})$ was added to intercalate bacterial membrane, and the polarization of TMA-DPH was measured at ex/em $360 \mathrm{~nm} / 460 \mathrm{~nm}$ by a 66 FP module at Microplate Reader. $\mathbf{b}$ Examination of $\beta$-galactosidase release. After treatment, the supernatants of particle treated cells were collected to incubate with $\beta$ galactosidase substrate for luminance examination. Columns and error bars represent the mean and the standard deviation of three replicates. ${ }^{* * *} p<0.001$ compared to controls by two-tailed Student's t-test 


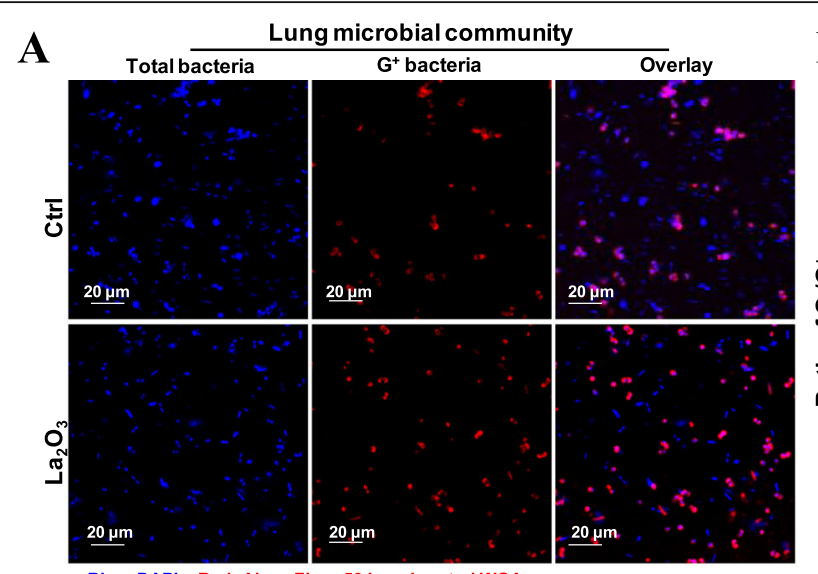

B

Blue: DAPI Red: Alexa Fluor 594 conjugated WGA

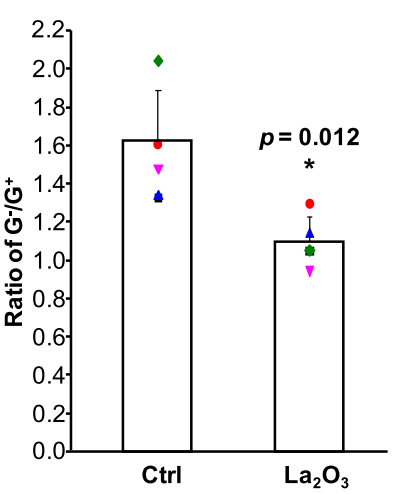

C

Inflammatory cytokines and cells in BALF
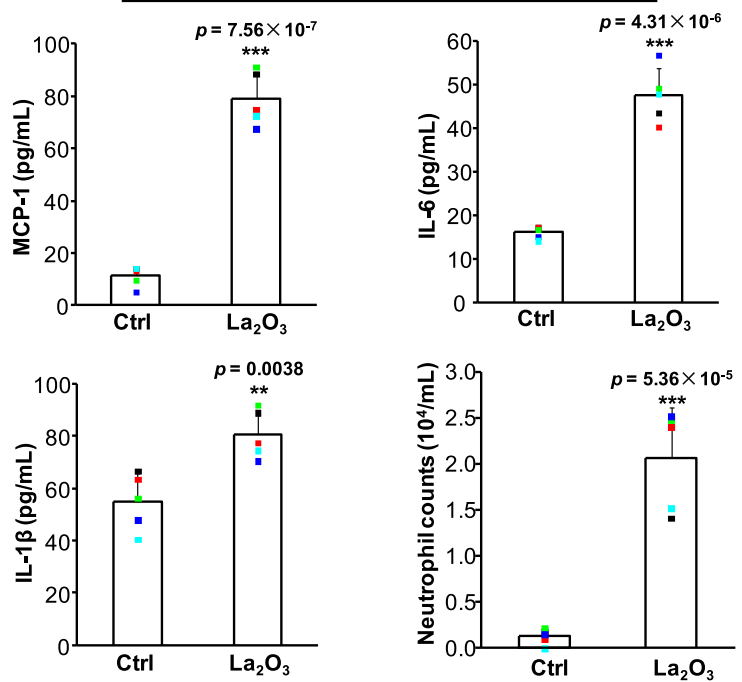

D

$\mathrm{La}_{2} \mathrm{O}_{3}$ with colistin

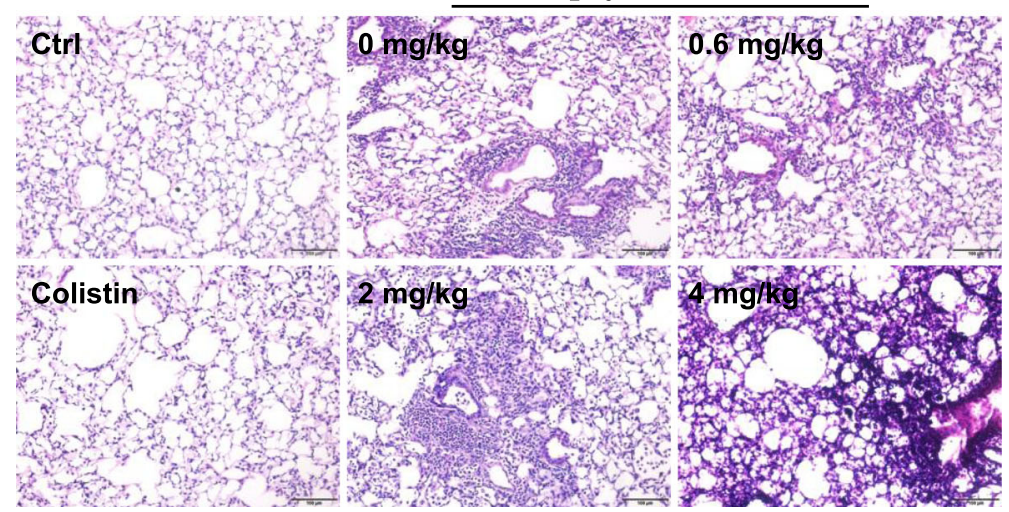

Fig. 5 (See legend on next page.) 
(See figure on previous page.)

Fig. 5 Evaluation of the disruption of $\mathrm{La}_{2} \mathrm{O}_{3}$ in lung. a The images of lung microbial communities. Animals were exposed to $2 \mathrm{mg} / \mathrm{Kg} \mathrm{La}_{2} \mathrm{O}_{3}$ by oropharyngeal aspiration for $24 \mathrm{~h}(n=5)$. Lung microbes were collected in BALF by centrifugation. The collected bacteria were subjected to confocal microscopy imaging after DAPI and Alex Flour 549 conjugated WGA staining. $\mathbf{b}$ The ratios of $\mathrm{G}^{+} / \mathrm{G}^{-}$. The percentage of $\mathrm{G}^{+}$and $\mathrm{G}^{-}$cells were calculated based on the confocal images. The ratios were presented as mean values \pm SD from five mice. ${ }^{*} p<0.05$ compared to control group by two-tailed Student's t-test. c Pro-inflammatory cytokine production and neutrophil counts in BALF. Immune cells in BALF were concentrated on glass slides by cytospin, fixed and stained by Quick-Diff for cell counting. Pro-inflammatory cytokines were determined by ELISA. Cell counting and cytokine data are presented as mean values \pm SD derived from five mice. ${ }^{* *} p<0.01$ and ${ }^{* *} p<0.001$ compared to controls by two-tailed Student's t-test. $\mathbf{d} \mathrm{H} \& \mathrm{E}$ staining images of lung tissues exposed to $\mathrm{La}_{2} \mathrm{O}_{3}$ with different concentrations of colistin. Mice exposed to saline or colistin were used as control groups. Scale bars represent $100 \mu \mathrm{m}$

has little effect in $\mathrm{G}^{+}$bacteria but specifically kills $\mathrm{G}^{-}$ bacteria. These microflora-disrupted mice were exposed to $\mathrm{La}_{2} \mathrm{O}_{3}$. As expected, dramatic reductions of $\mathrm{G}^{-} / \mathrm{G}^{+}$ratios (1.10 to 0.51 ) were detected in BALF of colistintreated mice (Figure S4). Notably, the pro-inflammatory cytokines (IL-6, IL-1 $\beta$ and MCP-1) as well as neutrophil counts were significantly increased along with the reduction of $\mathrm{G}^{-} / \mathrm{G}^{+}$ratios (Table 1). Both IL-6 and neutrophil cells showed strong correlations with $\mathrm{G}^{-} / \mathrm{G}^{+}$ratios, evidenced by their correlation coefficient $|\mathrm{r}|>0.8$. Consistently, $\mathrm{G}^{-} / \mathrm{G}^{+}$ratio dependent focal inflammation could be visualized around the airways of lungs exposed to $\mathrm{La}_{2} \mathrm{O}_{3}$ (Fig. 5d).

Besides that, the effects of $\mathrm{La}_{2} \mathrm{O}_{3}$ exposure to environmental microbiology were examined by Gram staining and $16 \mathrm{~S}$ rRNA sequencing. As shown in Figure S5, the ratio of $\mathrm{G}^{-} / \mathrm{G}^{+}$in soil microbial communities decreased from 1.96 to 1.07 after $\mathrm{La}_{2} \mathrm{O}_{3}$ exposure. To visualize the detailed microbial community changes induced by $\mathrm{La}_{2} \mathrm{O}_{3}$, the relative abundance values ( $\mathrm{Z}$ scores) of top 35 genera identified by $16 \mathrm{~S}$ rRNA-based sequencing were integrated into a heat map. As the visual data displayed, more than ten $\mathrm{G}^{-}$strains showed lower abundance in $\mathrm{La}_{2} \mathrm{O}_{3}$-treated soil microbial community (Figure S6A). Consistently, a significant decrement of $\mathrm{G}^{-} / \mathrm{G}^{+}$ratios could be detected in the soil microbial community after $\mathrm{La}_{2} \mathrm{O}_{3}$ exposure (Figure S6B).

\section{Discussion}

\section{Biotransformation of REOs elicited disruption of $\mathrm{G}^{-}$cell} membrane

Since MIEs play decisive role in adverse outcome pathways [26], we speculated that the MIEs at the nano-bio interfaces may be responsible for the distinct bactericidal effects of $\mathrm{La}_{2} \mathrm{O}_{3}$. Interestingly, $\mathrm{La}_{2} \mathrm{O}_{3}$ was found to associate with the membranes of $E$. coli cells and transform into needle-like $\mathrm{LaPO}_{4}$ precipitates. This is because lanthanides have strong binding affinity (Ksp $\sim 10^{-25.6}$ ) [27] with phosphate to form hexagonal structures. La ions might bind with two types of phosphates, including free phosphates in biosystem and conjugated phosphate moieties with biomolecules (phospholipids, phosphorylated proteins, etc) of membranes. We speculated that dephosphorylation of membrane biomolecules may be responsible for the bactericidal effects of $\mathrm{La}_{2} \mathrm{O}_{3}$. The dephosphorylated PC molecules and unchanged disaccharide molecules detected by mass spectrometry strongly suggested that the dephosphorylation of phospholipids on $\mathrm{G}^{-}$cell membranes might be the key MIE responsible for the bactericidal effects of rare earth nanoparticles.

MD simulation disclosed that $\mathrm{La}_{2} \mathrm{O}_{3}$-induced dephosphorylation resulted in bacterial membrane disruption with a much less ordered configuration, and thus increased the lateral and vertical diffusions of phospholipids. The results of $\beta$-galactosidase release revealed that $\mathrm{La}_{2} \mathrm{O}_{3}$ could induce an increment of membrane permeability, which was consistent with the MD result of increased lateral diffusions of phospholipids. Additionally, a fluorescent TMA-DPH probe capable of localizing membrane interiors for assessment of bacterial membrane fluidity in situ was exploited to testify the vertical diffusions of phospholipids. Specifically, $\mathrm{La}_{2} \mathrm{O}_{3}$ treatments induced a significant reduction of FP value in $G^{-}$cells compared to $G^{+}$cells, demonstrating an increased membrane fluidity of $\mathrm{G}^{-}$cell membrane. All considered, the disruption of membranes by $\mathrm{La}_{2} \mathrm{O}_{3}$ in

Table 1 Biological response in BALF after $\mathrm{La}_{2} \mathrm{O}_{3}$ and colistin exposure

\begin{tabular}{|c|c|c|c|c|}
\hline \multirow[t]{2}{*}{ Ratio of $\mathrm{G}^{-} / \mathrm{G}^{+}$} & \multicolumn{3}{|c|}{ Inflammatory cytokines (pg/mL) } & \multirow{2}{*}{$\begin{array}{l}\text { Cells }\left(10^{4}\right) \\
\text { Neutrophils }\end{array}$} \\
\hline & IL-1 $\beta$ & MCP-1 & IL-6 & \\
\hline $\mathrm{R} 1=1.10$ & $80.6 \pm 9.3$ & $78.9 \pm 10.3$ & $47.5 \pm 6.2$ & $2.1 \pm 0.6$ \\
\hline$R 2=0.74$ & $79.8 \pm 13.4$ & $78.0 \pm 15.1$ & $66.2 \pm 13.6$ & $6.7 \pm 1.9$ \\
\hline $\mathrm{R} 3=0.63$ & $80.0 \pm 17.3$ & $80.7 \pm 15.5$ & $108.1 \pm 15.7$ & $7.8 \pm 2.3$ \\
\hline $\mathrm{R} 4=0.51$ & $144.9 \pm 32.2$ & $135.4 \pm 24.5$ & $196.7 \pm 24.2$ & $14.6 \pm 2.3$ \\
\hline Pearson's correlation $|r|$ & 0.61 & 0.63 & 0.83 & 0.92 \\
\hline
\end{tabular}


$\mathrm{G}^{-}$bacterial cells likely involved four sequential processes: i) transformation of $\mathrm{La}_{2} \mathrm{O}_{3}$ into $\mathrm{LaPO}_{4}$; ii) dephosphorylation of phospholipids in $\mathrm{G}^{-}$cell membranes; iii) induction of an unordered configuration of phospholipids; iv) increment of both membrane fluidity and permeability.

\section{REOs causing microbiota imbalance}

Recent studies showed that bactericidal effects of REOs could be attributed to their impacts on biological media surrounding cells, ROS generation and metal ion release. For instance, $\mathrm{La}_{2} \mathrm{O}_{3}$ nanoparticles were found to scavenge phosphate from media to inhibit the growth of Escherichia coli, Staphylococcus carnosus, Penicillium roqueforti and Chlorella vulgaris [14]. The potential toxicity of $\mathrm{CeO}_{2}$ was ascribed to the ROS generation from the fast valence exchange between $\mathrm{Ce}(\mathrm{III})$ and $\mathrm{Ce}(\mathrm{IV})$ [28]. Additionally, ionic release from REO nanoparticles was also found to impact the viability of E. coli [29]. Although the toxic effects of REOs have been identified in a few bacteria strains, no attempts were made to differentiate the effects of REOs on $\mathrm{G}^{-}$and $\mathrm{G}^{+}$ cells. Our study disclosed the mechanisms of $\mathrm{La}_{2} \mathrm{O}_{3}-$ elicited imbalance of the lung and soil microbial communities. Moreover, severe pulmonary inflammatory responses were examined in $\mathrm{La}_{2} \mathrm{O}_{3}$ treatment by oropharyngeal aspiration, evidenced by the increments of neutrophil counts and cytokine release in BALF as well as focal inflammation in lung sections. These pathology changes may further lead to pneumoconiosis extensively reported in RE miners [30]. In terms of the toxicology mechanisms involved in rare earth pneumoconiosis, we have demonstrated a NLRP3 inflammasome pathway in macrophage-like cells responsible for REO-induced lung fibrosis by eliciting lysosomal damages, cathepsin B release, and IL-1 $\beta$ release [31]. While microbial communities have been recently found to play a major role in many diseases, including tumors [32], metabolic diseases [33], neurodegenerative disorders and inflammatory bowel diseases [34, 35], few studies explore the relationships between lung microflora imbalance and pulmonary diseases. In our study, lung toxicity results implied that microflora might play a protective role in $\mathrm{La}_{2} \mathrm{O}_{3}$-induced pulmonary inflammation. Since similar biotransformation behaviors have been identified in more REOs, such as $\mathrm{Gd}_{2} \mathrm{O}_{3}, \quad \mathrm{Nd}_{2} \mathrm{O}_{3}, \quad \mathrm{Sm}_{2} \mathrm{O}_{3}$, and $\mathrm{Yb}_{2} \mathrm{O}_{3}$ nanoparticles [31], these particles are likely to induce similar microbiota imbalance effects to $\mathrm{La}_{2} \mathrm{O}_{3}$. Moreover, we speculated that the impacts of microflora imbalance on pulmonary hazard effects induced by other stimuli (e.g., virus, air pollutants and fine particulates) may deserve more explorations.

\section{Relevance of REO doses and exposure routes in real scenarios}

Rare earth elements have wide applications in magnets, catalysts, metal alloys, electronics, glass, ceramics and new materials. There might be two major sources of nano-sized rare earth particles, including engineered rare earth nanoparticles and ultrafine particulates in RE industries. During the life cycle of rare earth nanoproducts, the particles have exposure risks to humans by inhalation, ingestion, dermal exposure and intravenous injection [7]. In addition, fine particulates from industries may be released into water, soil or air in RE mining, polishing and waste treatments. According to a Health Hazard Evaluation (HHE) report (No. HETA-88-01661944), OSHA's permissible exposure limit (PEL) for RE (e.g., Y, Nd and Dy) is $1 \mathrm{mg} / \mathrm{m}^{3}$. Based on a dose calculation equation for inhaled particulates (Formula S1 in Supplemental materials) [7, 36], a worker exposure to 1 $\mathrm{mg} / \mathrm{m}^{3}$ respirable dust for $8 \mathrm{~h} /$ day over a five-month time period over a 10 -year working time could lead to a lung burden of $2.2 \mathrm{mg} / \mathrm{m}^{2}$, which is comparable to 4.4 $\mathrm{mg} / \mathrm{Kg}$ NPs in mice. Assuming a homogeneous distribution of NP in alveoli, the corresponding in vitro NP dose would be $0-170 \mu \mathrm{g} / \mathrm{mL}$. In this study, the in vitro and in vivo doses of tested materials are at $0-250 \mu \mathrm{g} / \mathrm{mL}$ and $2 \mathrm{mg} / \mathrm{Kg}$, respectively. These doses are relevant to the possible occupational exposure in real scenarios.. In soil samples, the average concentrations of RE elements were reported to be $180 \mathrm{mg} / \mathrm{Kg}$ in China [37]. In our studies, $\mathrm{La}_{2} \mathrm{O}_{3}$ at $200 \mu \mathrm{g} / \mathrm{mL}$ was exposed to microbe communities extracted from $0.005 \mathrm{Kg}$ soils. It was equivalent to $200 \mathrm{mg} / \mathrm{Kg}$ RE nanoparticles in soil. Overall, the dosages of $\mathrm{La}_{2} \mathrm{O}_{3}$ tested in this study were relevant to real scenarios of occupational exposure in miners or soils close to RE mine. Due to the complexity and low abundance of pulmonary microflora, it's difficult to validate the bactericidal mechanism in animals. This challenge necessitated the exploration of culturomics for pulmonary microbes, including ex vivo high-throughput culture methods of pulmonary bacteria and high-sensitive analytical methods to identify low abundant microbes from a complex population. In terms of real respiratory scenarios, aerosol inhalation exposure is more relevant. The results acquired in this study may need further validations.

\section{Conclusion}

In this study, $\mathrm{La}_{2} \mathrm{O}_{3}$ was found to show significant toxicities on $\mathrm{G}^{-}$bacteria, but limited effects on $\mathrm{G}^{+}$cells. Biotransformation of $\mathrm{La}_{2} \mathrm{O}_{3}$ into $\mathrm{LaPO}_{4}$ at nano-bio interface elicited dephosphorylation of membrane phospholipids, a much less ordered configuration of phospholipids and increments of membrane fluidity and permeability. In real exposure scenarios, $\mathrm{La}_{2} \mathrm{O}_{3}$ was 
demonstrated to disrupt the balance of $\mathrm{G}^{-}$and $\mathrm{G}^{+}$bacteria in lung and soil microbial communities. Notably, we disclosed a strong correlation between microflora imbalance and lung inflammation in mouse lungs received $\mathrm{La}_{2} \mathrm{O}_{3}$ exposure. Overall, our study will provide a clearer and more comprehensive understanding of the hazard effects induced by REOs.

\section{Supplementary Information}

The online version contains supplementary material available at https://doi. org/10.1186/s12989-021-00410-5.

\section{Additional file 1.}

\section{Acknowledgements}

Not applicable.

\section{Authors' contributions}

H.Z. and R.L. conceived and designed the study. H.Z. performed most of the experiments. Z.Y., R.Z., Z.G. and S.L. performed MD simulations. Y.P. and W.L. synthesized the liposomes. J.C., Q.X and S.X. contributed in the animal experiments. X.C. contributed in LC-MS analysis. M.G. contributed in the analysis of soil microbial community. W.W. and X.L. contributed in the TEM and XRD characterizations. The author(s) read and approved the final manuscript.

\section{Funding}

This work was supported by the grant from the Key Projects for International Science and Technology Cooperation Program, Ministry of Science and Technology of China (2018YFE0120400), the National Natural Science Foundation of China (21806116, 21976126 and U1967217), the Key Projects of Social Development of Jiangsu Province (BE2018653) and the project funded by China Postdoctoral Science Foundation (No. 2019 M652069; 2019 T120506).

\section{Availability of data and materials}

All data displaying in this paper are available in a generalist repository, Harvard Dataverse, by following URL: https://dataverse.harvard.edu/dataset. xhtml?persistentld=doi:10.7910/DVN/2DG4YP

\section{Declarations}

Ethics approval and consent to participate

The animal study was approved by Committee of Animal Research and Ethics in Soochow University.

\section{Consent for publication}

Not applicable.

\section{Competing interests}

The authors declare no competing financial interest.

\section{Author details}

'State Key Laboratory of Radiation Medicine and Protection, School for Radiological and Interdisciplinary Sciences (RAD-X), Collaborative Innovation Center of Radiological Medicine of Jiangsu Higher Education Institutions, Soochow University, Suzhou 215123, Jiangsu, China. ${ }^{2}$ Institute of Quantitative Biology, Department of Physics, Zhejiang University, Hangzhou 310027, Zhejiang, China. ${ }^{3}$ School of Public Health, Jiangsu Key Laboratory of Preventive and Translational Medicine for Geriatric Diseases, Soochow University, Suzhou 215123, Jiangsu, China. ${ }^{4}$ Department of Chemistry, Columbia University, New York, NY 10027, USA.
Received: 5 January 2021 Accepted: 13 April 2021

Published online: 26 April 2021

\section{References}

1. Mus F, Crook MB, Garcia K, Garcia Costas A, Geddes BA, Kouri ED, et al. Symbiotic nitrogen fixation and the challenges to its extension to nonlegumes. Appl Environ Microbiol. 2016;82(13):3698-710. https://doi.org/1 0.1128/AEM.01055-16,

2. Yang Y, Kong G, Chen X, Lian Y, Liu W, Xu M. Electricity generation by Shewanella decolorationis $\$ 12$ without cytochrome c. Front Microbiol. 2017;8: 1115. https://doi.org/10.3389/fmicb.2017.01115.

3. Tirone C, Pezza L, Paladini A, Tana M, Aurilia C, Lio A, et al. Gut and lung microbiota in preterm infants: immunological modulation and implication in neonatal outcomes. Front Immunol. 2019;10:2910. https://doi.org/10.33 89/fimmu.2019.02910.

4. Khosravi A, Mazmanian SK. Disruption of the gut microbiome as a risk factor for microbial infections. Curr Opin Microbiol. 2013;16(2):221-7. https://doi. org/10.1016/j.mib.2013.03.009.

5. Zhang L, Nichols RG, Correll J, Murray IA, Tanaka N, Smith PB, et al. Persistent organic pollutants modify gut microbiota-host metabolic homeostasis in mice through aryl hydrocarbon receptor activation. Environ Health Perspect. 2015;123(7):679-88. https://doi.org/10.1289/ehp.1409055.

6. Poh TY, Ali N, Mac Aogain M, Kathawala MH, Setyawati MI, Ng KW, et al. Inhaled nanomaterials and the respiratory microbiome: clinical, immunological and toxicological perspectives. Part Fibre Toxicol. 2018;15(1): 46. https://doi.org/10.1186/s12989-018-0282-0.

7. Cai X, Liu X, Jiang J, Gao M, Wang W, Zheng H, et al. Molecular mechanisms, characterization methods, and utilities of nanoparticle biotransformation in nanosafety assessments. Small. 2020;16:1907663. https://doi.org/10.1002/smll.201907663.

8. Richter AP, Brown JS, Bharti B, Wang A, Gangwal S, Houck K, et al. An environmentally benign antimicrobial nanoparticle based on a silver-infused lignin core. Nat Nanotechnol. 2015;10(9):817-23. https://doi.org/10.1038/nna no.2015.141

9. Zhao $Y$, Jia $Y, X u$ J, Han L, He F, Jiang $X$. The antibacterial activities of $M_{0} S_{2}$ nanosheets towards multi-drug resistant bacteria. Chem Commun. 2021; 57(24):2998-3001. https://doi.org/10.1039/d1cc00327e.

10. Li R, Mansukhani ND, Guiney LM, Ji Z, Zhao Y, Chang CH, et al. Identification and optimization of carbon radicals on hydrated graphene oxide for ubiquitous antibacterial coatings. ACS Nano. 2016;12:10966-80.

11. Natalio F, Andre R, Hartog AF, Stoll B, Jochum KP, Wever R, et al. Vanadium pentoxide nanoparticles mimic vanadium haloperoxidases and thwart biofilm formation. Nat Nanotechnol. 2012;7(8):530-5. https://doi.org/10.103 8/nnano.2012.91.

12. Wu R, Chong Y, Fang G, Jiang X, Pan Y, Chen C, et al. Synthesis of pt hollow nanodendrites with enhanced peroxidase-like activity against bacterial infections: implication for wound healing. Adv Funct Mater. 2018;28: 1801484.

13. Tu Y, Lv M, Xiu P, Huynh T, Zhang M, Castelli M, et al. Destructive extraction of phospholipids from Escherichia coli membranes by graphene nanosheets. Nat Nanotechnol. 2013;8(8):594-601. https://doi. org/10.1038/nnano.2013.125.

14. Gerber LC, Moser N, Luechinger NA, Stark WJ, Grass RN. Phosphate starvation as an antimicrobial strategy: the controllable toxicity of lanthanum oxide nanoparticles. Chem Commun (Camb). 2012;48(32):386971. https://doi.org/10.1039/c2cc30903c.

15. Zheng H, Ji Z, Roy KR, Gao M, Pan Y, Cai X, et al. Engineered graphene oxide nanocomposite capable of preventing the evolution of antimicrobial resistance. ACS Nano. 2019;13(10):11488-99. https://doi.org/10.1021/acsna no.9b04970.

16. Qi Y, Ingolfsson HI, Cheng X, Lee J, Marrink SJ, Im W. Charmm-gui martini maker for coarse-grained simulations with the martini force field. J Chem Theory Comput. 2015;11(9):4486-94. https://doi.org/10.1021/acs.jctc. 5 b00513.

17. Jo S, Kim T, lyer VG, Im W. Charmm-gui: a web-based graphical user interface for charmm. J Comput Chem. 2008;29(11):1859-65. https://doi. org/10.1002/jcc.20945.

18. Hsu PC, Bruininks BMH, Jefferies D, de Souza PCT, Lee J, Patel DS, et al. Charmm-gui martini maker for modeling and simulation of complex bacterial membranes with lipopolysaccharides. J Comput Chem. 2017; 38(27):2354-63. https://doi.org/10.1002/jcc.24895. 
19. Abraham MJ, Murtola T, Schulz R, Pall S, Smith JC, Hess B, et al. Gromacs: high performance molecular simulations through multi-level parallelism from laptops to supercomputers. SoftwareX. 2015;1-2:19-25. https://doi. org/10.1016/j.softx.2015.06.001.

20. Marrink SJ, Risselada HJ, Yefimov S, Tieleman DP, de Vries AH. The martini force field: coarse grained model for biomolecular simulations. J Phys Chem B. 2007;111(27):7812-24. https://doi.org/10.1021/jp071097f.

21. Bussi G, Donadio D, Parrinello M. Canonical sampling through velocity rescaling. J Chem Phys. 2007;126(1):014101. https://doi.org/10.1063/1.24 08420.

22. Parrinello M, Rahman A. Polymorphic transitions in single-crystals - a new molecular-dynamics method. J Appl Phys. 1981;52(12):7182-90. https://doi. org/10.1063/1.328693.

23. Liu L, Zhang S, Zhao L, Gu Z, Duan G, Zhou B, et al. Superior compatibility of $\mathrm{C} 2 \mathrm{~N}$ with human red blood cell membranes and the underlying mechanism. Small. 2018;14:e1803509.

24. Liu S, Shen Z, Wu B, Yu Y, Hou H, Zhang XX, et al. Cytotoxicity and efflux pump inhibition induced by molybdenum disulfide and boron nitride nanomaterials with sheetlike structure. Environ Sci Technol. 2017;51(18): 10834-42. https://doi.org/10.1021/acs.est.7b02463.

25. Cardiff RD, Miller CH, Munn RJ. Manual hematoxylin and eosin staining of mouse tissue sections. Cold Spring Harb Protoc. 2014;2014(6):655-8. https:// doi.org/10.1101/pdb.prot073411.

26. Allen TE, Goodman JM, Gutsell S, Russell PJ. Defining molecular initiating events in the adverse outcome pathway framework for risk assessment. Chem Res Toxicol. 2014;27(12):2100-12. https://doi.org/10.1021/tx500345j.

27. Buda AR, Church C, Kleinman PJ, Saporito LS, Moyer BG, Tao L. Using rare earth elements to control phosphorus and track manure in runoff. J Environ Qual. 2010;39(3):1028-35. https://doi.org/10.2134/jeq2009.0359.

28. Auffan M, Rose J, Wiesner MR, Bottero JY. Chemical stability of metallic nanoparticles: a parameter controlling their potential cellular toxicity in vitro. Environ Pollut. 2009;157(4):1127-33. https://doi.org/10.1016/j. envpol.2008.10.002.

29. He X, Pan Y, Zhang J, Li Y, Ma Y, Zhang P, et al. Quantifying the total ionic release from nanoparticles after particle-cell contact. Environ Pollut. 2015; 196:194-200. https://doi.org/10.1016/j.envpol.2014.09.021.

30. Corrin B, Nicholson AG. Occupational, environmental and iatrogenic lung disease; 2011.

31. Li R, Ji Z, Chang CH, Dunphy DR, Cai X, Meng H, et al. Surface interactions with compartmentalized cellular phosphates explain rare earth oxide nanoparticle hazard and provide opportunities for safer design. ACS Nano. 2014;8(2):1771-83. https://doi.org/10.1021/nn406166n.

32. Le Noci V, Guglielmetti S, Arioli S, Camisaschi C, Bianchi F, Sommariva M, et al. Modulation of pulmonary microbiota by antibiotic or probiotic aerosol therapy: a strategy to promote immunosurveillance against lung metastases. Cell Rep. 2018;24(13):3528-38. https://doi.org/10.1016/j.celrep.2 018.08.090.

33. Karlsson F, Tremaroli V, Nielsen J, Backhed F. Assessing the human gut microbiota in metabolic diseases. Diabetes. 2013;62(10):3341-9. https://doi org/10.2337/db13-0844.

34. Cryan JF, O'Riordan KJ, Sandhu K, Peterson V, Dinan TG. The gut microbiome in neurological disorders. Lancet Neurol. 2020;19(2):179-94. https://doi.org/10.1016/S1474-4422(19)30356-4.

35. Roy U, Galvez EJC, Iljazovic A, Lesker TR, Blazejewski AJ, Pils MC, et al. Distinct microbial communities trigger colitis development upon intestinal barrier damage via innate or adaptive immune cells. Cell Rep. 2017;21(4): 994-1008. https://doi.org/10.1016/j.celrep.2017.09.097.

36. Xu S, Zheng H, Ma R, Wu D, Pan Y, Yin C, et al. Vacancies on $2 \mathrm{D}$ transition metal dichalcogenides elicit ferroptotic cell death. Nat Commun. 2020;11(1): 3484. https://doi.org/10.1038/s41467-020-17300-7.

37. Li J, Hong $M$, Yin X, Liu J. Effects of the accumulation of the rare earth elements on soil macrofauna community. J Rare Earths. 2010;28(6):957-64. https://doi.org/10.1016/S1002-0721(09)60233-7.

\section{Publisher's Note}

Springer Nature remains neutral with regard to jurisdictional claims in published maps and institutional affiliations.

Ready to submit your research? Choose BMC and benefit from:

- fast, convenient online submission

- thorough peer review by experienced researchers in your field

- rapid publication on acceptance

- support for research data, including large and complex data types

- gold Open Access which fosters wider collaboration and increased citations

- maximum visibility for your research: over $100 \mathrm{M}$ website views per year

At BMC, research is always in progress.

Learn more biomedcentral.com/submissions 